\title{
WOMEN OF LETTERS
}

GENDER, WRITING AND THE LIFE OF THE MIND IN EARLY MODERN ENGLAND

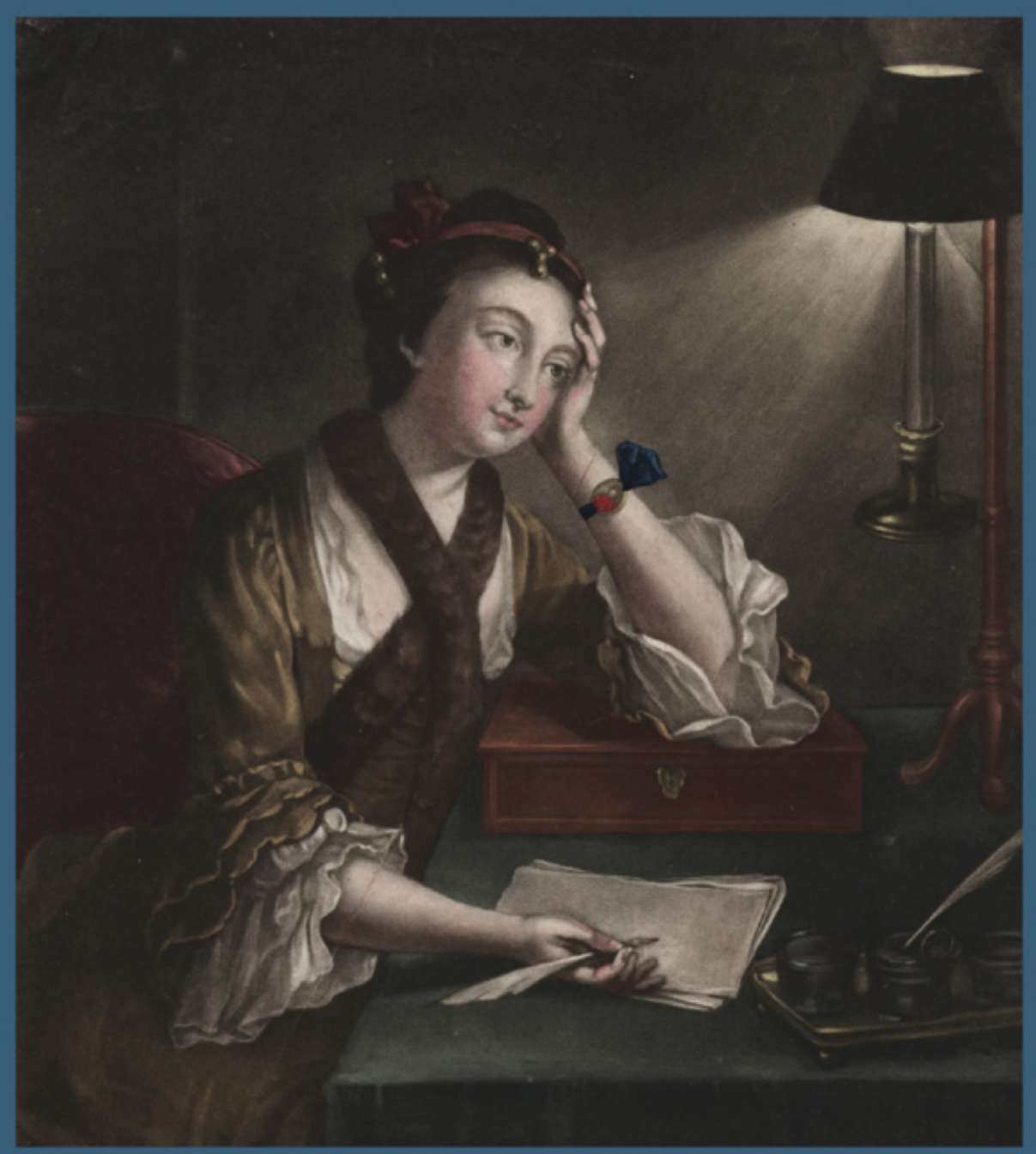

$\leftarrow$ Leonie Hannan $\approx$ 
Leonie Hannan - 9781784997694

Downloaded from manchesterhive.com at $04 / 26 / 2023$ 10:49:18AM 


\section{GENDER IN HISTORY}

Series editors:

Lynn Abrams, Cordelia Beattie, Pam Sharpe and Penny Summerfield

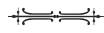

The expansion of research into the history of women and gender since the $1970 \mathrm{~s}$ has changed the face of history. Using the insights of feminist theory and of historians of women, gender historians have explored the configuration in the past of gender identities and relations between the sexes. They have also investigated the history of sexuality and family relations, and analysed ideas and ideals of masculinity and femininity. Yet gender history has not abandoned the original, inspirational project of women's history: to recover and reveal the lived experience of women in the past and the present.

The series Gender in History provides a forum for these developments. Its historical coverage extends from the medieval to the modern periods, and its geographical scope encompasses not only Europe and North America but all corners of the globe. The series aims to investigate the social and cultural constructions of gender in historical sources, as well as the gendering of historical discourse itself. It embraces both detailed case studies of specific regions or periods, and broader treatments of major themes. Gender in History titles are designed to meet the needs of both scholars and students working in this dynamic area of historical research.

\section{Women of letters}

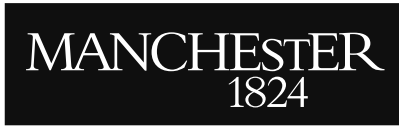

Manchester University Press 


\section{OTHER RECENT BOOKS}

IN THE SERIES

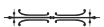

Love, intimacy and power: marriage and patriarchy in Scotland, 1650-1850 Katie Barclay

(Winner of the 2012 Women's History Network Book Prize)

Modern women on trial: sexual transgression in the age of the flapper Lucy Bland

The Women's Liberation Movement in Scotland Sarah Browne

Modern motherhood: women and family in England, c. 1945-20oo Angela Davis

Gender, rhetoric and regulation: women's work in the civil service and the London County Council, 1900-55 Helen Glew

Jewish women in Europe in the Middle Ages: a quiet revolution Simha Goldin

The shadow of marriage: singleness in England, 1914-6o Katherine Holden

Women, dowries and agency: marriage in fifteenth-century Valencia Dana Wessell Lightfoot

Women, travel and identity: journeys by rail and sea, 1870-1940 Emma Robinson-Tomsett

Imagining Caribbean womanhood: race, nation and beauty contests, 1929-7o Rochelle Rowe

Infidel feminism: secularism, religion and women's emancipation, England 1830-1914 Laura Schwartz

Women, credit and debt in early modern Scotland Cathryn Spence

Being boys: working-class masculinities and leisure Melanie Tebbutt

Queen and country: same sex desire in the British Armed Forces, 1939-45 Emma Vickers

The 'perpetual fair': gender, disorder and urban amusement in eighteenth-century London Anne Wohlcke 


\section{WOMEN OF LETTERS}

GENDER, WRITING AND THE LIFE OF THE MIND IN EARLY MODERN ENGLAND

$\oiiint$ Leonie Hannan

Manchester University Press 


\section{Copyright ( $\odot$ Leonie Hannan 2016}

The right of Leonie Hannan to be identified as the author of this work has been asserted by her in accordance with the Copyright, Designs and Patents Act 1988.

Published by Manchester University Press

Altrincham Street, Manchester M1 7JA

www.manchesteruniversitypress.co.uk

British Library Cataloguing-in-Publication Data

A catalogue record for this book is available from the British Library

Library of Congress Cataloging-in-Publication Data applied for

ISBN 978 o 719099427 hardback

First published 2016

The publisher has no responsibility for the persistence or accuracy of URLs for any external or third-party internet websites referred to in this book, and does not guarantee that any content on such websites is, or will remain, accurate or appropriate.

Typeset by Out of House Publishing 